\title{
Detection of exogenous floating marine debris: an overview of techniques associated with remote sensing
}

\author{
M. L. B. Paige \& M. Painho \\ NOVA IMS, Universidade Nova de Lisboa, Portugal
}

\begin{abstract}
Exogenous floating marine debris (EFMD) is a worldwide concern and its ubiquitous characteristics and long-term threat have raised calls for new venues to enable easier and prompt detection at large. The main focus of this paper is to evidence search and detection methods for EFMD using remote sensing techniques. This paper contributes to update research information in the topic under scrutiny and to screen for possible gaps to mitigate EFMD impacts. Several needs for research were found, and, before any work to establish the ground truth could take place, a spectral library model for EFMD going through several stages of biofouling must be created using passive or active research methods. Search methods need to be automated using empirical models based on stratified set-ups previously tested. Several sensors show potential for an indirect search for EFMD, but direct detection of EFMD using multispectral and radar instruments still needs further research through integration with conceptual and empirical modeling techniques.

Keywords: floating debris, marine debris, marine litter, remote sensing, search techniques, detection techniques, indirect and direct methods.
\end{abstract}

\section{Introduction}

Because the use of the term exogenous floating marine debris (EFMD) is found in the literature to be synonymous with very distinct concepts such as, exogenous floating debris, floating marine debris, floating debris, and marine debris, a definition for these concepts should be a prime consideration. EFMD can be defined as solid materials of human or land origin that in some way reach the sea and, due to its long-term buoyancy characteristics, stay afloat for a period of time 
long enough to have an impact on human or faunal populations and their habitats. Contrary to EFMD, exogenous floating debris (EFD) can reach any water body. Floating marine debris (FMD) is EFMD associated with organic debris produced within the oceanic system, such as, algae or shells. Floating debris (FD) is these EFD associated with organic debris originated or not within the marine system itself. Marine debris (MD) comprehends all debris found in any non-freshwater body, independently of its origins, characteristics, and permanency in the medium under consideration.

A wide scope of the known negative impacts of EFMD is present in the literature, but the most pressing and maybe not yet completely understood are those which might lead to up-down, bottom-up and horizontal effects through populations and ecosystems. An example of a possible unforeseen case of foodchain disruption with negative lateral consequences is when plastic microparticles are physically absorbed by at least one of its elements. For instance, zooplankton feeding capability [1] and algae photosynthetic production are impaired [2] if such occurs. This is only the tip of the iceberg for the connection between EFMD pollution and marine environmental health, since, according to Moore et al. [3], dramatic findings of 6:1 particulate plastic/neuston ratio was found for the North Pacific.

Anther physical negative expression of EFMD presence is related with specific habitats or its users, which, for instance, is differentiated positively to threatened habitats and populations. Examples of known effects on individuals and populations are as follows: the disruption of satiation, feeding and breeding mechanisms [4, 5], entanglement [6-11], and the spread of exotic and dangerous organisms $[12,13]$. Moreover, the decrease of tourism and fishing activity [14, 15] and the increase of accidents at sea are also a concern [5].

The major accumulation and sinking areas for the EFMD are relatively well studied by, for example, Howell et al. [16], Martinez et al. [17], and Pruter [18]. They raised some light on the accumulation of EFMD in gyres ("garbage patches") and other hot spots as a result of the convergence of oceanic currents. For instance, taking into account meso- and large-scale spatial variability, Howell et al. [16] and Martinez et al. [17] studied the mechanisms associated with the EFMD concentration, transport and retention in some of those convergence zones for, respectively, the North Pacific and the South Pacific. Morishige et al. [19] found also a more seasonal effect related with a quantitative relationship between EFMD deposition on the French Frigate Shoals and the El Nino/El Nina phenomenon.

Because EFMD show a wide range of sizes [20-22] and is of distinct origins and compositions [20, 23-26], its aggregating and distribution patterns, influenced by systemic trendy variation in the ocean wind stress and heat patterns, vary through time and are also location dependent. Besides, fouling communities on floating debris change through the oceanic permanence time and contribute also towards its detection problem by changing its buoyancy, floating stability [27], and even reflectance characteristics. Of course, all of these aspects make the detection of EFMD challenging and so there is a need to look for new break-through scientific approaches. 
The significant costs associated with direct sampling techniques, i.e., associated with direct "field work" in a given study area, have made it prohibitive to implement them worldwide in a systematic approach. Moreover, with the advent of an increasing number of remote sensing and modeling applications being made available at increasingly low costs, changes in the methodological techniques of search and detection of EFMD must be observed. These alterations should create a synergist point break, necessary to rise a more demanding rational to have readily available outputs to, e.g., easily monitor illegal dumping, monitor outputs resulting from environmental disasters, improve rescues at sea in case of ship or plane accidents, and implement efficient collection methods for EFMD.

Even knowing that both the surveying methods associated with the water column, sea-bottom, and beaches, and species indicators and habitats are indirect proxies to study EFMD dynamics, these methods, unless a remote sensing technique is used, are not referred to in this paper because they include a vast range of dispersive methodologies that cannot be aggregated lightly under the remote sensing umbrella.

Taking into account that the research question defined for this paper is, Can remote sensing help mitigate negative impacts of EFMD on oceanic systems?, the present paper aims, one the one hand, to make a brief overview of some search and detection strategies present in the literature and associated with remote sensing technologies. On the other, a complementary section of recommended research aspects designed to understand EFMD dynamic behavior is presented. The paper is divided as follows: after the definition of objectives in the introductory part, a brief overview of search and detection techniques (definitions and historical overview) is introduced, and the work ends with a discussion section and the conclusions.

\section{Search and detection techniques for EFMD: definitions}

Before starting to describe some of the search methodologies found in the literature, it is important to define some of the terminology used, such as: direct versus indirect methods, object oriented versus proxy oriented detection, and active versus passive methodologies.

While direct methods use visual or aided visual inspection to locate debris, which, once found, can be readily removed or not from the affected area, indirect methods, which are usually used to aid clean-up crews, are very diverse in nature and can use a wide array of approaches relying on a given proxy for EFMD search or detection. Some examples of the latter are, forecasting and eddy detection methods, the prospection of biological or specific habitats to use as indicators of the EFMD quantity and quality, and methods of integration concerning previous knowledge about the system (Table 1). Any of the direct and indirect methods can be used within the context of other methods such as, object or proxy detection, and active or passive methodologies. Direct detection techniques for beach and sea bottom MD are, within the EFMD context, considered as indirect techniques. While examples of direct techniques for beach 
sediments using aerial photographs [28-30] or uniform color space aerial photographs to detect plastic [31] are present in the literature, direct search and detection for sea bottom MD usually focus on coral reef health studies (e.g., Dameron et al. [32]). However, the greatest problem related with beach, water column and sea-bottom indirect techniques to understand EFMD behavior relies on the lack of diffusion models with well-defined rates and processes between the diverse components of the systems at hand, i.e., beach, sea-bottom, water column, and open sea surface water.

Object oriented methods of search and detection, as foreseen by their nomenclature, are those targeted to detect directly or indirectly the EFMD through the use of a given detectable MD object. Proxy oriented methods use surrogates to understand EFMD dynamics (e.g., use of an indicator for plastics, such as, Northern fulmars [33]), and, as with object oriented methods, can be understood within an active or passive context. Active and passive methodologies are associated, respectively, with those requiring or not an in loco experimental approach to be addressed.

Spatial sampling can be systematic or stratified. The systematic method is usually used for systems where little previous knowledge exists and an efficient sampling of the study area is primordial [34]. It is within this methodology, that the tessellated hexagons technique was developed by White et al. [35] to preserve an equal area grid approach [34]. Stratified sampling usually uses indirect methods of search and detection to focalize the effort within a search area [34].

\section{Search and detection techniques for EFMD: historical overview}

Due to the comparative dimension of the EFMD and the ocean, not only the detection techniques to be used in any study need to be evaluated punctually, but the search approach, which cannot be forgotten as an important effort constraint for each area under surveillance, must be carefully chosen. Several search and detection approaches have been found in the literature associated with remote sensing techniques (Table 1). Among the indirect methods we have the following with interest for a remote sensing discussion: ocean modeling using Lagrangian drifters, and eddies behavior and algae accumulation using altimeter information, Light Detection and Ranging (Lidar), and Synthetic Aperture Radar (SAR) data. Several oceanic circulation models have been established to overview back- and forward-casting of EFMD distribution paths, accumulation sinks, and environmental forcing constraints $[36,37]$. The techniques provided global or regional settings for circulation by relying on several sources of information such as water temperature and surface winds satellite data to model possible dispersion paths, and buoys, Lidar or SAR imagery for eddy detection.

Within this context, Leberton et al. [36] created, based on realistic scenarios, a global ocean circulation model coupled to a Lagrangian particle-tracking set-up to simulate several years of input, transport and accumulation of floating debris. A random walk with separated lateral and longitudinal coefficients was used in 
Table 1: Examples of remote sensing studies classified for EFMD, using distinct approaches of search and detection.

\begin{tabular}{|c|c|c|c|c|c|c|}
\hline $\begin{array}{l}\text { Detection } \\
\text { methods }\end{array}$ & $\begin{array}{c}\text { Search } \\
\text { methods }\end{array}$ & $\begin{array}{l}\text { MD/species/ } \\
\text { habitat types }\end{array}$ & Study area & $\begin{array}{c}\text { Study } \\
\text { objective }\end{array}$ & $\begin{array}{c}\text { Remote } \\
\text { sensing } \\
\text { imagery } \\
\text { used }\end{array}$ & Reference \\
\hline \multirow[t]{3}{*}{$\begin{array}{l}\text { Indirect, } \\
\text { passive }\end{array}$} & $\begin{array}{c}\text { Object } \\
\text { oriented }\end{array}$ & $\begin{array}{c}\text { Macroplastic } \\
\text { debris, } \\
\text { beaches }\end{array}$ & $\begin{array}{c}\text { Tobishima } \\
\text { island, Japan }\end{array}$ & $\begin{array}{l}\text { Detection } \\
\text { of plastic } \\
\text { pixels of } \\
\text { any color }\end{array}$ & Webcam & $\begin{array}{c}\text { Kataoka et } \\
\text { al. [31] }\end{array}$ \\
\hline & $\begin{array}{c}\text { Proxy } \\
\text { oriented }\end{array}$ & $\begin{array}{c}\text { Depth, } \\
\text { habitat } \\
\text { classification } \\
\text { - proxies for } \\
\text { coral reefs } \\
\text { area }\end{array}$ & $\begin{array}{l}\text { Nothwestern } \\
\text { Hawaiian } \\
\text { islands, USA }\end{array}$ & $\begin{array}{l}\text { Estimate } \\
\text { MD } \\
\text { accumulati } \\
\text { on }\end{array}$ & IKONOS & $\begin{array}{c}\text { Dameron et } \\
\text { al. [32] }\end{array}$ \\
\hline & $\begin{array}{c}\text { Proxy } \\
\text { oriented }\end{array}$ & $\begin{array}{l}\text { Chlorophyll- } \\
\text { a, surface } \\
\text { temperature - } \\
\text { eddies } \\
\text { detection }\end{array}$ & $\begin{array}{c}\text { Senegal, } \\
\text { West Africa }\end{array}$ & $\begin{array}{c}\text { Eddies } \\
\text { detection }\end{array}$ & $\begin{array}{c}\text { Aqua/ } \\
\text { MODIS } \\
\text { AVHRR/ } \\
\text { ASAR }\end{array}$ & $\begin{array}{c}\text { Alpers et al. } \\
\text { [38] }\end{array}$ \\
\hline \multirow[t]{3}{*}{$\begin{array}{l}\text { Direct, } \\
\text { passive }\end{array}$} & $\begin{array}{c}\text { Object } \\
\text { oriented }\end{array}$ & $\begin{array}{l}\text { tsunami } \\
\text { EFMD }\end{array}$ & $\begin{array}{c}\text { Okirai bay, } \\
\text { Japan }\end{array}$ & $\begin{array}{c}\text { EFMD } \\
\text { detection } \\
\text { by size and } \\
\text { estimate } \\
\text { velocity }\end{array}$ & $\begin{array}{c}\text { ALOS } \\
\text { PALSAR }\end{array}$ & $\begin{array}{l}\text { Arii et al. } \\
{[39]}\end{array}$ \\
\hline & & $\begin{array}{l}\text { tsunami } \\
\text { EFMD }\end{array}$ & $\begin{array}{c}\text { Tohoku, } \\
\text { Japan }\end{array}$ & $\begin{array}{l}\text { EFMD } \\
\text { detection }\end{array}$ & $\begin{array}{c}\text { Terra/ } \\
\text { MODIS }\end{array}$ & $\begin{array}{c}\text { Aoyama } \\
{[40]}\end{array}$ \\
\hline & & $\begin{array}{c}\text { metallic } \\
\text { objects }\end{array}$ & $\begin{array}{l}\text { Atlantic } \\
\text { Ocean, off } \\
\text { Brazilian } \\
\text { coast }\end{array}$ & $\begin{array}{l}\text { crashed } \\
\text { aircraft } \\
\text { detection }\end{array}$ & $\begin{array}{l}\text { X-band } \\
\text { COSMO- } \\
\text { SkyMed }\end{array}$ & $\begin{array}{c}\text { Paes et al. } \\
{[41]}\end{array}$ \\
\hline
\end{tabular}

this study to simulate turbulence. Maximenko et al. [42] used a global set of trajectories of satellite-tracked Lagrangian drifters to study worldwide EFMD dynamics. They took into account the geography and specificities of accumulation zones under study. This approach illustrated the combined effect of the floating object geometry, the wind and upper-oceanic currents. Using a global ocean model (HYCOM/NCODA) to simulate the transport and accumulation of 2011 Japanese tsunami floating debris, Leberton and Borrero [43] found its provable accumulation in the North Pacific subtropical gyre. Reahard et al. [44], on other hand, created fore- and backtracking simulations using satellite based sea surface height and height anomaly to assess sources and transport of EFMD at sea.

Pichel et al. [45], within the GhostNet project, used, besides a circulation model, wind and current models associated with tagged buoys to determine 
convergence areas for EFMD. Pichel et al. [46] developed a likelihood estimate of encountering concentrations of MD in a specific area - debris estimated likelihood index (DELI) - using a combination of sea surface temperature, chlorophyll-a and chlorophyll-a gradient. However, and according to Morishige and McElwee [47], ground-truthing is a gap inherent of this model.

Under the remote sensing array, and within an object oriented search and detection classification for EFMD, one of the most important aspects for consideration is the imagery type. The passive sensors use the energy reflected or emitted by the objects, and can vary from: RGB (red, green, blue) video, digital cameras, multispectral and hyperspectral sensors, thermal imagers [48], and Moderate Resolution Imaging Spectroradiometer (MODIS) [40]. An aspect to ponder when selecting a sensor is, taking into account the characteristics of the EFMD to detect, the existence of a trade off between spatial coverage and spatial resolution. RGB video has an important weakness by presenting a false detection rate related to the intrinsic variability in light and surface characteristics [48]. Mutispectral sensors, by presenting seven bands, might, according to Veenstra and Churnside [48], turn out to be useful in detecting EFMD. Hyperspectral cameras with thirty bands, and spectral resolution of 10 nanometers or less, show also some promising attributes to detect EFMD in shallow waters [48]. The thermal imagers detect heat radiated at $3-5$ or $7-14$ micrometer wavelengths bands, but did not perform very well with, at least, derelict fishing gear [48].

After the 2011 earthquake off the Japanese Pacific coast, earth observation satellites were used to monitor the damage caused by the disaster and to monitor the tsunami EMFD [40]. Aoyama [40] used pseudo-color images R:G:B band1: band2: band1 - from Terra/MODIS with a spatial resolution of $250 \mathrm{~m}$ to detect them. He proposed, in this way, a method to identify EFMD using twodimensional scatter diagrams for the chosen spectral bands. The drawback for the MODIS usage is related with its sensitivity to weather and daytime conditions, and by presenting a lower spatial resolution than SAR. Harris et al. [49], using multispectral imagery from WorldView-2, complemented this information by creating a spectral library for some EFMD usually found at sea.

A few examples of active sensors used to detect EFMD are, Lidar and radar. Green laser Lidar showed auspicious results to detect differential algae clumping patterns [45], while fluorescence Lidar is promising to detect phytoplankton [48]. SAR, phased array L-band SAR - PALSAR - mounted on the Advanced Land Observing Satellite - ALOS - was used by Arii et al. [39] to sense tsunami EFMD, since its imagery is characterized by, regardless of the weather and time of day, a higher resolution than MODIS with flexible operability. According to those authors [39], the swath width of no more than $200 \mathrm{~km}$ should be taken into account when monitoring EFMD and the resolution should be $50 \mathrm{~m}$ or less. However, when detecting small isolated debris a fine resolution of less than $10 \mathrm{~m}$ should be considered. 


\section{Discussion}

It is particularly important to conjointly use distinct types of remote sensing sensors for search and detection of EFMD since, in this way, the differential positive characteristics of each method are potentiated [34, 48]. However, according to Mace [34], a crucial step is associated with the development of a strata approach of search and detection for a successful EFMD clean up strategy. Direct methods for EFMD, using multispectral and radar instruments, reached a stall with storm-related items, but a new urge of research was found based on indirect search and detection methods for EFMD based on the differential algae clumping patterns on eddies. This trend is reassured by a clear concentration of research on the behavior of eddies around the world for the last years (e.g., Crawford et al. [50], Karimovaa et al. [51], Liu et al. [52], and Rogachev [53]) and this residual knowledge might mark a later trend for EFMD detection and search techniques. However, still further investigation is needed to follow the promising role of indirect measurements for EFMD search and detection. Indirect methods of EFMD search relying on Lagrange settings are useful to understand the underlying aspects of its distribution and concentration, but unless the techniques are implemented in a regional setting, such as is done in the works of Pichel et al. [45], Reahard et al. [44] and Yoon et al. [54], its interest for implementing clean up strategies and understanding EFMD patchiness behavior in the water column is limited within a remote sensing framework.

Studies of biofouling on EFMD are now going under a rising bloom of research and have been taking two main venues to understand the following: (1) succession time frames associated with it [55-59] and (2) its impact on the EFMD intrinsic capabilities to withstand on the surface water [27, 56, 57, 60]. All those aspects are important to predict EFMD behavior and to better target the methods used for search and detection. However, unless spectral signatures are obtained for all the phases of EFMD residence at sea, its use, within a remote sensing setting, might be limited. Spectral signatures for plastics are under scrutiny for a near infrared aperture [61, 62], but, for an effective remote sensing setting, a need for the full spectrum of all EFMD is crucial to further deepen the research in this area.

\section{Conclusions}

It is important that efforts be directed to collect all instances of EFMD before it particulates and further damage in the oceanic system occurs. The focus, on the light of EFMD, must be concentrated on the behavior, distribution and techniques used for its search and detection. Many more studies need to be undertaken in looking for cost-effective and easy-to-implement techniques for the search and detection of EFMD, so a call for research in this area is still in place. Thus, various aspects related with EFMD still remain in the work, and, among those, two are very promising for future research: (1) to study the intrinsic and extrinsic spectral behavior of EFMD taking into account all the 
aspects that may demise its prompt location at sea using a remote sensing setting, and (2) conceptual and empirical modeling for all the aspects concerning EFMD search and detection. Besides, the successful method for EFMD detection must resolve the issues related with the daunting task of distinguishing between them and the surrounding environment, by dealing with the fouling dynamics, and, according to McElwee et al. [63], partially submersed objects, sea state (e.g., white caps), solar reflectance and other non-target items.

\section{References}

[1] Cole, M., Lindeque, P., Fileman, E., Halsband, C., Goodhead, R., Moger, J., et al., Microplastic Ingestion by Zooplankton. Environmental Science \& Technology, 47, pp. 6646-6655, 2013.

[2] Bhattacharya, P., Lin, S., Turner, J.P. \& Ke, P.C., Physical adsorption of charged plastic nanoparticles affects algal photosynthesis. Journal of Physical Chemistry C, 114, pp. 16556-16561, 2010.

[3] Moore, C.J., Moore, S.L., Leecaster, M.K. \& Weisberg, S.B., A comparison of plastic and plankton in the North Pacific central gyre. Marine Pollution Bulletin, 42, pp. 1297-1300, 2001.

[4] Gregory, M.R., Environmental implications of plastic debris in marine settings - entanglement, ingestion, smothering, hangers-on, hitch-hiking and alien invasions. Philosophical Transactions of the Royal Society B, 364, pp. 2013-2025, 2009.

[5] National Research Council, 2. Understanding marine debris and its impact. In: Tackling marine debris on the 21 st century, Ed. Committee on the Effectiveness of International and National Measures to Prevent and Reduce Marine Debris and Its Impacts, National Research Council. The National Academies Press. ISBN-13: 978-0-309-12697-7. http://www.nap.edu/catalog.php?record id=12486.

[6] Arnould, J.P.Y. \& Croxall, J.P., Trends in entanglement of Antarctic fur seals (Arctocephalus gazella) in man-made debris at South Georgia. Marine Pollution Bulletin, 30, pp. 707-712, 1995.

[7] Carr, A., Impact of non-degradable marine debris on the ecology and survival outlook of sea turtles. Marine Pollution Bulletin, 18, pp. 352-356, 1987.

[8] Moore, E., Lyday, S., Roletto, J., Litle, K., Parrish, J.K., Nevins, et al., Entanglements of marine mammals and seabirds in central California and the north-west coast of the United States 2001-2005. Marine Pollution Bulletin, 58, pp. 1045-1051, 2009.

[9] Phillips, R.A., Ridley, C., Reid, K., Pugh, P.J.A., Tuck, G.N. \& Harrison, N., Ingestion of fishing gear and entanglements of seabirds: monitoring and implications for management. Biological Conservation, 143, pp. 501$512,2010$.

[10] Sazima, I., Gadig, O.B.F., Namora, R.C. \& Motta, F.S., Plastic debris collars on juvenile carcharhinid sharks (Rhizoprionodon lalandii) in southwest Atlantic. Marine Pollution Bulletin, 44, pp. 1149-1151, 2002. 
[11] Williams, R., Ashe, E., \& O'Hara, P.D., Marine mammals and debris in coastal waters of British Columbia, Canada. Marine Pollution Bulletin, 62, pp. 1303-1316, 2011.

[12] McIlgorm, A., Campbell, H.F. \& Rule, M.J., Understanding the economic benefits and costs of controlling marine debris in the APEC region (MRC 02/2007). A report to the Asia-Pacific Economic Cooperation Marine Resource Conservation Working Group by the National Marine Science Centre (University of New England and Southern Cross University), Coffs Harbour, NSW, Australia, December. APEC Project MRC 02/2007, 2008.

[13] USEPA, Invasive species. United States Environmental Protection Agency. http://www.epa.gov/greatlakes/invasive/.

[14] Galgani, F., Leaute, J.P., Moguedet, P., Souplet, A., Verin, Y., Carpentier, A., et al., Litter on the sea floor along European Coasts. Marine Pollution Bulletin, 40, pp. 516-527, 2000.

[15] Richards, Z.T. \& Berger, M., A quantification of the standing stock of macro-debris in Majuro Lagoon and its effect on hard coral communities. Marine Pollution Bulletin, 62, pp. 1693-1703, 2011.

[16] Howell, E.A., Bograd, S.J., Morishige, C., Seki, M.P. \& Polovina, J.J., On North Pacific circulation and associated marine debris concentration. Marine Pollution Bulletin, 65, pp. 16-22, 2012.

[17] Martinez, E., Maamaatuaiahutapu, K. \& Taillandier, V., Floating marine debris surface drift: convergence and accumulation toward the South Pacific subtropical gyre. Environmental Science \& Technology, 58, pp. 1347-1355, 2009.

[18] Pruter, A.T., Sources, quantities and distribution of persistent plastics in the marine environment. Marine Pollution Bulletin, 18, pp. 305-310, 1987.

[19] Morishige, C., Donohue, M.J., Flint, E., Swenson, C. \& Woolaway, C., Factors affecting marine debris deposition at French Frigate Shoals, Northwestern Hawaiian Islands Marine National Monument, 1990-2006. Marine Pollution Bulletin, 54, pp. 1162-1169, 2007.

[20] Ribic, C.A., Sheavly, S.B. \& Klavitter, J., Baseline for beached marine debris on Sand Island, Midway Atoll. Marine Pollution Bulletin, 64, pp. 1726-1729, 2012.

[21] Ryan, P.G., Moore, C.J., van Francker, J.A., \& Moloney, C.L., Monitoring the abundance of plastic debris in the marine environment. Philosophical Transactions of the Royal Society B, 364, pp. 1999-2012, 2009.

[22] Thompson, R.C., Moore, C.J., Vom Saal, F.S. \& Swan, S.H., Plastics, the environment and human health: current consensus and future trends. Philosophical Transactions of the Royal Society B, 364, pp. 2153-2166, 2009.

[23] Cole, M., Lindeque, P., Halshand, C. \& Galloway, T.S., Microplastics as contaminants in the marine environment: a review. Marine Pollution Bulletin, 62, pp. 2588-2597, 2011.

[24] Derraik, J.G.B., The pollution of the marine environment by plastic debris: a review. Marine Pollution Bulletin, 44, pp. 842-852, 2002. 
[25] Moore, C.J., Synthetic polymers in the marine environment: a rapidly increasing long-term threat. Environmental Research, 108, pp. 131-139, 2008.

[26] Topçu, E.N., Tonay, A.M., Dede, A., Öztürk, A.A. \& Öztürk, B., Origin and abundance of marine litter along sandy beaches of the Turkish Western Black Sea Coast. Marine Environmental Research, 85, pp. 21-28, 2013.

[27] Bravo, M., Astudillo, J.C., Lancellotti, D., Luna-Jorquera, G., Valdivia, N. \& Thiel, M., Rafting on abiotic substrata: properties of floating items and their influence on community succession. Marine Ecology Progress Series, 439, pp. 1-17, 2011.

[28] Kako, S., Isobe, A. \& Magome, S., Sequential monitoring of beach litter using webcams. Marine Pollution Bulletin, 60, pp. 775-779, 2010.

[29] Kako, S., Isobe, A. \& Magome, S., Low altitude remote-sensing method to monitor marine and beach litter of various colors using a balloon equipped with a digital camera. Marine Pollution Bulletin, 64, pp. 1156-1162, 2012.

[30] Nakashima, E., Isobe, A., Magome, S., Kako, S. \& Deki, N., Using aerial photography and in situ measurements to estimate the quantity of macrolitter on beaches. Marine Pollution Bulletin, 62, pp. 762-769, 2011.

[31] Kataoka, T., Hinata, H. \& Kako, S., A new technique for detecting colored macro plastic debris on beaches using webcam images and CIELUV. Marine Pollution Bulletin, 64, pp. 1829-1836, 2012.

[32] Dameron, O.J., Parke, M., Albins, M.A. \& Brainard, R., Marine debris accumulation in the Northwestern Hawaiian Islands: an examination of rates and processes. Marine Pollution Bulletin, 54, pp. 423-433, 2007.

[33] Avery-Gomm, S., O’Hara, P.D., Kleine, L., Bowes, V., Wilson, L.K. \& Barry, K.L., Northern fulmars as biological monitors of trends of plastic pollution in the eastern North Pacific. Marine Pollution Bulletin, 64, pp. 1776-1781, 2012.

[34] Mace, T.H., At-sea detection of marine debris: overview of technologies, processes, issues, and options. Marine Pollution Bulletin, 65, pp. 23-27, 2012.

[35] White, D., Kimerling, A.J. \& Overton, W.S., Cartographic and geometric components of a global sampling design for environmental monitoring. Cartography and Geographic Information Systems, 19(1), pp. 5-22, 1992.

[36] Lebreton, L.C.-M., Greer, S.D. \& Borrero, J.C., Numerical modelling of floating debris in the world's oceans. Marine Pollution Bulletin, 64, pp. 653-661, 2012.

[37] Zarfl, C., Fleet, D., \& Fries, E., Microplastics in oceans. Marine Pollution Bulletin, 62, pp. 1589-1591, 2011.

[38] Alpers, W., Brandt, P., Lazar, A., Dagorne, D., Sow, B., Faye, S., et al., A small-scale oceanic eddy off the coast of West Africa studied by multisensor satellite and surface drifter data. Remote Sensing of Environment, 129, pp. 132-143, 2013.

[39] Arii, M, Aoki, Y. \& Koiwa, M., Effective monitoring for marine debris after Great East Japan earthquake by using spaceborne synthetic aperture 
radar, Proc. SPIE Remote Sensing of the Marine Environment II, eds. R.J. Frouin, N. Ebuchi, D. Pan \& T. Saino, 8525(852503), 2012.

[40] Aoyama, T., Monitoring of debris flow in the ocean generated by huge tsunami caused by the 2011 off the Pacific coast of Tohoku earthquake. Proc. SPIE Remote Sensing of the Marine Environment II, eds. R.J. Frouin, N. Ebuchi, D. Pan \& T. Saino, vol. 8525(852513), 2012.

[41] Paes, R.L., Nunziata, F., Shiguemori, E.H., Migliaccio, M. \& Montuori, A., COSMO-SkyMed SAR data to observe small metallic objects from ocean crashed aircraft. Proc. IGARSS Vancouver 2011, IEEE International Geoscience and Remote Sensing Symposium, pp. 2869-2872, 2011.

[42] Maximenko, N., Hafner, J. \& Niiler, P., Pathways of marine debris derived from trajectories of Lagrangian drifters. Marine Pollution Bulletin, 65, pp. 51-62, 2012.

[43] Lebreton, L.C.-M. \& Borrero, J.C., Modeling the transport and accumulation floating debris generated by the 11 March 2011 Tohoku tsunami. Marine Pollution Bulletin, 66, pp. 53-58, 2013.

[44] Reahard, R., Mitchell, B., Lee, L., Mallett, C., Albin, A. \& Barrett, S., Spaceborn sensors track marine debris circulation in the Gulf of Mexico, Proc. Pecora 18 - Forty Years of Earth Observation...Understanding a Changing World, November 14-17, Herndon, Virginia, 2011.

[45] Pichel, W.G., Veenstra, T.S., Churnside, J.H., Arabini, E., Friedman, K.S., Foley, D.G., et al., GhostNet marine debris survey in the Gulf of Alaska Satellite guidance and aircraft observations. Marine Pollution Bulletin, 65, pp. 28-41, 2012.

[46] Pichel, W.G., Churnside, J.H., Veenstra, T.S., Foley, D.G., Friedman, K.S., Brainard, R.E., et al., Marine debris collects within the North Pacific Subtropical Convergence Zone. Marine Pollution Bulletin, 54, pp. $1207-$ 1211, 2007.

[47] Morishige, C. \& McElwee, K., At-sea detection of derelict fishing gear in the North Pacific: an overview. Marine Pollution Bulletin, 65, pp. 1-6, 2012.

[48] Veenstra, T.S. \& Churnside, J.H., Airborne sensors for detecting large marine debris at sea. Marine Pollution Bulletin, 65, pp. 63-68, 2012.

[49] Harris, T., Strett, D., Belge, J., Ramirez, E., Jankot, J., Vogt, J., et al., Spectral target detection for detecting and characterizing floating marine debris. EXELIS. American Geophysical Union, Fall meeting, 2012.

[50] Crawford, W.R., Brickley, P. \& Thomas, A.C., Mesoscale eddies dominate surface phytoplankton in northern Gulf of Alaska. Progress in Oceanography, 75, pp. 287-303, 2007.

[51] Karimovaa, S.S., Lavrovaa, O.Y. \& Solov'evb, D.M., Observation of eddy structures in the Baltic Sea with the use of radiolocation and radiometric satellite data. Izvestiya, Atmospheric and Oceanic Physics, 48(9), pp. 1006-1013, 2012.

[52] Liu, Y., Dong, C., Guan, Y., Chen, D., McWilliams, J. \& Nencioli, F., Eddy analysis in the subtropical zonal band of the North Pacific Ocean. Deep-Sea Research I, 68, pp. 54-67, 2012. 
[53] Rogachev, K.A., Satellite observations of regular eddies in bays of the Shantar Archipelago, Sea of Okhotsk. Izvestiya, Atmospheric and Oceanic Physics, 48(9), pp. 993-998, 2012.

[54] Yoon, J.-H., Kawano, S. \& Igawa S., Modeling of marine litter drift and beaching in the Japan sea. Marine Pollution Bulletin, 60, pp. 448-463, 2010.

[55] Lobelle, D. \& M. Cunliffe, Early microbial biofilm formation on marine plastic debris. Marine Pollution Bulletin, 62, pp. 197-200, 2011.

[56] Muthukumar, T., Aravinthan, A., Lakshmi, K., Venkatesan, R., Vedaprakash, L. \& Doble, M., Fouling and stability of polymers and composites in marine environment. International Biodeterioration \& Biodegradation, 65, pp. 276-284, 2011.

[57] Myan, F.W.Y., Walker, J. \& Paramor, O., The interaction of marine fouling organisms with topography of varied scale and geometry: a review. Biointerphases, 8, pp. 1-30, 2013.

[58] Satheesh, S. \& Wesley, S.G., Influence of submersion season on the development of test panel biofouling communities in a tropical coast. Estuarine, Coastal and Shelf Science, 94, pp. 155-163, 2011.

[59] Zettler, E.R., Mincer, T.J. \& Amaral-Zettler, L.A., Life in the "plastisphere": microbial communities on plastic marine debris. Environmental Science \& Technology, 47, pp. 7137-7146, 2013.

[60] Artham, T. \& Doble, M., Fouling and degradation of polycarbonate in seawater: field and lab studies. Journal of Polymers and the Environment, 17, pp. 170-180, 2009.

[61] Broek, W.H.A.M. van den, Derks, E.P.P.A., Ven, E.W. van de, Wienke, D., Geladi, P. \& Buydens, L.M.C., Plastic identification by remote sensing spectroscopic NIR imaging using kernel partial least squares (KPLS). Chemometrics and Intelligent Laboratory Systems, 35, pp. 187-197, 1996.

[62] Broek, W.H.A.M. van den, Wienke, D., Melssen, W.J. \& Buydens, L.M.C., Plastic material identification with spectroscopic near infrared imaging and artificial neural networks. Analytica Chimica Acta, 361, pp. 161-176, 1998.

[63] McElwee, K., Donohue, M.J., Courtney, C.A., Morishige, C. \& RiveraVicente, A., A strategy for detecting derelict fishing gear at sea. Marine Pollution Bulletin, 65, pp. 7-15, 2012. 